\title{
Industrial Waste Whey as a Low-Cost, Efficient, and Environmentally Safe Disinfectant, with Potential Applications for Minimally Processed Foodstuff
}

\author{
Maria Isabel S. Santos ${ }^{1,2}$, Ana Isabel G. Lima1,2, Laurentina Pedroso ${ }^{1,2}$ \\ and Isabel Sousa ${ }^{1^{*}}$
}

DOI: 10.9734/bpi/castr/v14/10188D

\begin{abstract}
Being a fast and reliable way to access healthy products, fresh-cut fruit and vegetables are becoming a rapidly rising sector of the horticultural industry with a concomitant high consumer demand. Freshcut processing usually involves sanitizing steps, with chlorine washing being the general choice. Due to the health harming effects of chlorine, there has been an increasing demand for alternative disinfecting agents. Under this context, fermented cheese whey has shown potential as a natural sanitizing agent but has been poorly tested in fresh-cut produce. Furthermore, it also continues to pose an environmental problem because it still contains a high organic load.

Here we aimed at developing a low-cost, scalable fermentation protocol to produce a disinfectant from dairy waste that has very little organic content and high levels of lactic acid. Fermentation was achieved with industrial whey from ewe, goat, and cow's milk, using a specific mesophilic-lactic acid bacteria starter mix over a more prolonged fermentation of $120 \mathrm{~h}$, which yielded the highest lactic acid production and the lowest lactose content. Antibacterial activity was observed against Listeria monocytogenes, Salmonella enterica, and Escherichia coli O157:H7, plus a total of thirteen other food pathogenic and spoilage strains, and antibacterial activities were determined to be highest after $120 \mathrm{~h}$. We further validated this whey's application as a disinfectant in shredded lettuce and compared its efficacy to that of chlorine, evaluating microbial quality, texture, color, and sensory perception, $\mathrm{pH}$, and $\mathrm{O}_{2}$ and $\mathrm{CO}_{2}$ determinations. Results showed that not only was microbial quality better when using our whey solution $(p<0.05)$, but also the quality indicators for whey were statistically similar to those treated with chlorine. Hence, our work validates the use of an industrial waste whey as a low-cost, efficient, and environmentally safe disinfectant, with potential applications for minimally processed foodstuffs as an alternative to chlorine.
\end{abstract}

Keywords: Fermented whey; antimicrobial; minimally processed vegetables; quality markers; sensory evaluation; disinfection; chlorine alternative.

\section{INTRODUCTION}

Whey is an industrial by-product resulting from cheese manufacture. Approximately $89 \%$ of the milk used for cheese manufacture is processed into whey [1]. Due to its high organic matter content, it holds a high chemical oxygen demand (COD), hence posing a considerable pollution problem [2-5], meaning that currently there are very restrictive legislations regarding whey disposal $[6,7]$. Hence, a novel trend for finding emerging alternative uses has risen, with one of them being the reuse of whey as a disinfecting agent [8-10]. The increasingly recognized antibacterial potential of whey is mostly due to the presence of lactic acid and antibacterial bioactive peptides [11-13], both resulting from the cheese fermentation process [14-16]. Being a food product by nature, whey has been suggested to

\footnotetext{
${ }^{1}$ Linking Landscape Environment, Agriculture and Food (LEAF), Instituto Superior de Agronomia (ISA), Universidade de Lisboa, Tapada da Ajuda, 1349-017 Lisbon, Portugal.

${ }^{2}$ Faculty of Veterinary Medicine, Universidade Lusófona de Humanidades e Tecnologias, Campo Grande, 376, 1749-024 Lisbon, Portugal.

${ }^{\star}$ Corresponding author: E-mail: isabelsousa@isa.ulisboa.pt;
} 
hold particular interest as a disinfectant in freshly-cut fruit and vegetables, or minimally processed produce (MPP), which in turn are becoming major health concerns because of highly frequent pathogen outbreaks $[17,18]$. Indeed, several studies have reported the presence of strains such as Shiga toxin-producing Escherichia coli, Salmonella spp., and Listeria monocytogenes in MPP, with the last one causing death rates as high as $20 \%$ in high risk groups [17-22], followed by Salmonella spp., with a reported frequency of $4-8 \%[23,24]$. Moreover, currently, chlorine is the most common disinfectant used in the fresh-cut industry [25] and it poses a serious environmental and health hazard, with strong evidences of carcinogenic problems, mostly due to the formation of toxic derivatives, such as chloramines and trihalomethanes. Therefore, restrictions to the use of chlorinated solutions are starting to arise [25-27], which consequentially has led to an increasingly higher demand to find new sanitizers [28,29]. However, as demonstrated by several published works [25,30-32], most of these alternatives are high in cost and induce odor and alterations to the organoleptic properties of the foods to which they are applied. Hence, the development of novel, cost-effective, and natural disinfectants for MPP foods is of very high economical and industrial interest. Overall, whey seems to be a promising alternative to chlorine as a disinfectant [33], and furthermore Lactic Acid Bacteria (LAB) species have been proposed as protective cultures for minimally processed food, because of their great potential for bio-control of pathogenic bacteria $[34,35]$ and their generally recognized safe status (generally recognized as safe - GRAS, Grade One status) [36]. However, using whey or whey permeate as a disinfectant in food would result in the same environmental problem because it still contains a high load of organic matter. This could be partially overcome by fermenting the whey itself, which promotes the removal of proteins as well as lactose, and thus reduces its COD. Another direct effect of this processing is a higher production of lactic acid from lactose, which can increase its antibacterial activity, and in the case of whey proteins, it can also yield specific polypeptide sequences with antibacterial activity [37,38], which can increase its potential as a sanitizer. Nonetheless, most works use up to $24 \mathrm{~h}$ of fermentation [33,39], which is not enough to eliminate organic matter content. Also, it is very important to ensure that the fermented whey does not alter the organoleptic properties of the minimally processed (MP) produce, since unprocessed whey, or whey permeate, can induce visual and odor alterations to the product. However, very few works have tested whey, fermented or not, in a realistic manner in MP vegetables, particularly those more sensitive to decay, such as shredded loose-leaf lettuce. Hence, in this work, we aimed to develop a low-cost, scalable way to produce a disinfectant from dairy waste that has very little organic content and high levels of lactic acid, and induces little to no alterations in food quality.

Hence, we developed a fermentation protocol of whey from mixed origin (cow, ewe, goat) based on previous works $[40,41]$ and evaluated its $c$. The goal was to produce the highest amount of lactic acid, whilst reducing lactose in a low-cost and efficient manner, and to determine its applications to control relevant pathogens isolated from vegetable foods, all the while maintaining food quality and safety. We also aimed to determine its efficacy against chlorine in salad disinfection. Overall, our work validated the use of an industrial waste whey as a low-cost, healthy, and efficient disinfectant that can replace chlorine, with potential applications on minimally processed foods.

\section{MATERIALS AND METHODS}

\subsection{Whey Fermentation}

The whey used for fermentation was collected after cheese manufacture from a mixture of ewe, goat, and cow's milk using an industrial starter mix (Danisco, Sassenage, France) of Lactococcus lactis subsp. lactis, Lactococcus lactis subsp. cremoris, Lactococcus lactis subsp. lactis biovar diacetylactis, Streptococcus thermophilus, and Lactobacillus delbrueckii subsp. bulgaricus, containing approximately $10^{7} \mathrm{cfu} \cdot \mathrm{mL}^{-1}$ of whey. It was kept at $-18^{\circ} \mathrm{C}$ until fermentation assays. Bacterial cell enumeration was performed on Man Rogosa and Sharp medium (MRS broth) (Biokar Diagnostic ${ }^{\top M}$, Beauvais, France), containing $2 \%(\mathrm{w} / \mathrm{v})$ agar (Difco, Quilaban, Portugal). Incubation was done at $37^{\circ} \mathrm{C} \pm 1^{\circ} \mathrm{C}$ for $48 \mathrm{~h} \pm 2$ h. The samples of whey were obtained after manufacture of cheese from a mixture of ewe, goat, and cow's milk, containing 0.04\% (w/v) NaCl, pH 6.65 (Lab 850, Schott AG, Mainz, Germany) and $30 \mathrm{~g} \cdot \mathrm{L}^{-1}$ lactose, quantified by HPLC (High-performance liquid chromatography) ion exchange chromatography, as in a previous work [41], was used for the fermentation assays. Whey was divided into $500 \mathrm{~mL}$ aliquots in Erlenmeyer flasks, and assays were conducted at $37^{\circ} \mathrm{C}$ for $120 \mathrm{~h}$. Over time, at regular 
Current Approaches in Science and Technology Research Vol. 14 Industrial Waste Whey as a Low-Cost, Efficient, and Environmentally Safe Disinfectant, with Potential Applications for Minimally Processed Foodstuff

intervals, $5 \mathrm{~mL}$ samples were taken for $\mathrm{pH}$ measurement (Lab 850, Schott AG, Mainz, Germany) and HPLC determinations, as previously described by Santos et al. [41].

\subsection{Biochemical Analysis}

The quantification of sugars and acids throughout the fermentation assays were done by HPLC (Waters Corporation, Milford, MA, USA), equipped with a 515 HPLC Pump (Waters Corporation, Milford, MA, USA) and incorporated with a Refractive Index Detector (RID) 486 (Waters Corporation, Milford, MA, USA). Prior to injection, samples were centrifuged at $10.000 \mathrm{rpm} / 10 \mathrm{~min}$ and the supernatants were filtered through a Millipore membrane with a pore size of $0.2 \mu \mathrm{m}$. Samples were injected in a Schodex SC-1011 column (Waters Corporation, Milford, MA, USA) and separations were achieved at $50{ }^{\circ} \mathrm{C}$, using $5 \mathrm{mM}$ sulphuric acid as mobile phase (isocratic elution), at a flow rate of 0.6 $\mathrm{mL} \cdot \mathrm{min}^{-1}$. Calibration curves and peak integration were performed as already described by Santos et al. [41].

\subsection{Determination of Antibacterial Activities}

Gram-positive bacteria species used to assess antibacterial activity of fermented whey dilutions were Listeria monocytogenes NCTC 11994 (serovar 4b), L. innocua ATCC 33090 (type strain) (Instituto Superior de Agronomia - ISA, Lisboa, Portugal), Staphylococcus aureus ATCC 6538 (Instituto Nacional de Saúde Dr. Ricardo Jorge - INSA, Lisboa, Portugal), Bacillus subtilis, and B. cereus, which were isolated from a chickpea salad with parsley at the Food Microbiology Laboratory (FML-INSA). The Gram-negative strains tested were: Salmonella enterica serovar Typhimurium ATCC 14028 (ISA), S. enterica serovar Goldcoast NCTC 13175, Escherichia coli NCTC 9001, Escherichia coli O157:H7 NCTC 12900 (verotoxin negative), Pseudomonas aeruginosa ATCC 27853, P. fluorescens ATCC 13525 (INSA), Pantoa agglomerans, and Citrobacter freundii, which were isolated from a lettuce salad at FML-INSA. Strains were recovered from a culture at $-80^{\circ} \mathrm{C}$, into $10 \mathrm{~mL}$ of Brain Heart Infusion Broth (BHI) (Oxoid, Bansingstone, UK) for two consecutive cultures at $24 \mathrm{~h}$ intervals, inoculated afterwards on Tryptone Soya Agar (TSA) (bioMérieux ${ }^{\circledR}$ SA, Marcy l'Étoile, France) and incubated at $37^{\circ} \mathrm{C} \pm 1{ }^{\circ} \mathrm{C}$ overnight. Chlorine was used as a positive control.

\subsubsection{Minimum Inhibitory Concentration (MIC) throughout the $120 \mathrm{~h}$ fermentation}

In a first approach, antibacterial activities were tested throughout the length of the five-day fermentation, with L. monocytogenes and Escherichia coli O157.H7. Minimum Inhibitory Concentration (MIC) determinations were determined using suspensions of L. monocytogenes and Escherichia coli O157:H7 from overnight cultures, which were prepared in Müller-Hinton Broth medium ((Biokar Diagnostics $^{\mathrm{TM}}$ Beauvais, France) adjusted to a final optical density (OD) of $0.12\left(2 \times 10^{8} \mathrm{cfu} \cdot \mathrm{mL}^{-1}\right)$ [42], read at $546 \mathrm{~nm}$ in a spectrophotometer (Boeco S-20, Hamburg, Germany). Further decimal dilutions were made in the same medium to obtain final suspensions of $2 \times 10^{5} \mathrm{cfu} \cdot \mathrm{mL}^{-1}$. MIC values were assessed in sterile 96-well plates (Greiner Bio-one, Germany), using the micro dilution method of Bouhdid et al. [43]. Plates were incubated for $24 \mathrm{~h} \pm 2 \mathrm{~h}$, at $37^{\circ} \mathrm{C} \pm 1{ }^{\circ} \mathrm{C}$, and the OD was read at 546 $\mathrm{nm}$ (Synergy HT, Biotek, Winooski, VT, USA) in the beginning of the inoculation and at the end of the assay.

\subsubsection{Well-diffusion assay}

After selecting the day that presented the highest antibacterial activity, fermented whey (100\%) was tested on a second screen for its antibacterial activity against several food outburst-related bacterial species, using the well-diffusion assay described by Rizzello et al. [11], modified by incorporation of inoculum into Plate Count Agar (bioMerieux, Marcy l'Etoile, France), $10 \mathrm{~mL}$ per plate, overlaid with 10 $\mathrm{mL}$ of water-agar $(2 \% \mathrm{w} / \mathrm{v})$. Wells of $15 \mathrm{~mm}$ were cut into agar plates and $200 \mu \mathrm{L}$ of $120 \mathrm{~h}$ fermented whey were placed in each well. Plates remained at $4^{\circ} \mathrm{C}$ for $4 \mathrm{~h}$ to allow diffusion. 
To test dose-dependence, we also compared non-fermented whey, fermented whey, and milk against the strain of $L$. monocytogenes, using diluted solutions of 100,50 , and $25 \%(\mathrm{v} / \mathrm{v})$. After incubation at $37^{\circ} \mathrm{C} \pm 1^{\circ} \mathrm{C}, 24 \mathrm{~h} \pm 2 \mathrm{~h}$, plates were measured with a caliper rule for inhibition zone diameters, with averages of three independent trials calculated with standard deviations. As a positive control we used an anionic detergent surfactant and susceptibility was recorded by average diameters $>4 \mathrm{~mm}$ [44].

\subsection{Impact of Fermented Whey as a MP Lettuce Sanitizer}

Loose leaf lettuce (Lactuca sativa var. crispa) samples were purchased at a local biological market, always from the same organic grower, on the same day of the experiments. Samples were treated in parallel with whey solution and a $110 \mathrm{ppm}$ chlorine solution by dissolving Amokina ${ }^{\circledR}$ (Angelini, Portugal) in sterile water, according to the manufacturer instructions. Outer leaves of the lettuces with signs of damage were discarded; the inner ones were cut using a cylindrical metal cutter of $6 \mathrm{~cm}$ diameter in order to take representative portions of all parts of the plant tissue. Circles of lettuce leaves were than washed in distilled water. Subsequently, three different solutions were used to sanitize and wash the lettuce shreds: (1) Distilled water acting as the reference; (2) chlorinated solution (110 ppm of Amokina $\left.{ }^{\circledR}\right)$, as previously described; and $(3)$ a $75 \%(\mathrm{v} / \mathrm{v})$ fermented whey solution in distilled water [41]. The three different treatments were carried out in plastic bags filled with about $200 \mathrm{~g}$ of lettuce shreds, from the three different zones of the lettuces (outer, inner, and middle leaves) immersed in $1 \mathrm{~L}$ of the sanitizing or washing solutions. Bags were sealed and soaked for 5 min at $4{ }^{\circ} \mathrm{C}$ using an incubator with orbital shaking (Panasonic MIR 154, Gunma, Japan). After that, lettuce shreds were rinsed with sterile distilled water to remove sanitizers, and finally, the excess surface water was removed by a handheld salad spinner (IKEA Tokig, Lisbon, Portugal) for about $30 \mathrm{~s}$. Processed lettuce were pooled and packed at $100 \mathrm{~g}$ of shredded lettuce per bag in heat-sealing bags $(300 \times 230 \mathrm{~mm})$ of $30 \mu \mathrm{m}$ oriented polypropylene (Amcor Flexibles Neocel, Portugal), graciously granted by Campotec SA. A bag prepared with $100 \mathrm{~g}$ of lettuce just soaked in distilled water, whose excess was also removed by the salad spinner, was marked as day 0 and served as the reference. To evaluate $\mathrm{O}_{2}$ and $\mathrm{CO}_{2}$ changes, three independent bags were separated. Samples were stored at $4{ }^{\circ} \mathrm{C}$ for subsequent evaluation of $\mathrm{O}_{2}$ and $\mathrm{CO}_{2}$ changes, $\mathrm{pH}$, texture, color, sensory quality, and microbial growth, on processing day (day 0 ) and after $1,3,5,7,9$, and 10 days of storage. The experiments were performed in three independent trials.

\subsection{1 pH measurement}

The samples were prepared by mixing $10 \mathrm{~g}$ of each sample with $20 \mathrm{~mL}$ of deionized water in sterile stomacher bags (Seward Limited, London, UK) and then homogenized in a Stomacher (Model 400 Circulator, Seward Limited, London, UK) for $2 \mathrm{~min}$ at regular speed. Afterwards, the $\mathrm{pH}$ of samples was measured with a Metrohm $827 \mathrm{pH}$ Lab with a 6.0228.010 Primatrode, electrode with integrated temperature sensor (NTC) (Metrohm, Herisau, Switzerland).

\subsubsection{Texture analysis}

The texture features of lettuce samples were evaluated in a puncture test with a texturometer TAXTplus (Stable MicroSystems, Godalming, UK) using a $5 \mathrm{~kg}$ load cell. Each sample was fixed between a perforated plate and an acrylic ring with a $9.7 \mathrm{~mm}$ hole, as in a sandwich, and kept in place by a plastic clip to avoid any slipping. A $2 \mathrm{~mm}$ diameter inox probe penetrated ( $5 \mathrm{~mm}$ distance) the sample through the hole in the rin, at $1 \mathrm{~mm} / \mathrm{s}$ crosshead speed. From the force-distance texturogram, two parameters were evaluated: firmness, as the maximum rupture force $(\mathrm{N})$ in the yy axis; and brittleness, defined as the rupture deformation $(\mathrm{mm})$, corresponding to the distance of the peak on the $\mathrm{xx}$ axis.

\subsubsection{Color measurement}

Sample color was measured on the CIELAB L*a*b* chromatic space with a Minolta CR-300 colorimeter (Minolta, Osaka, Japan) with standard illuminant D65 and a visual angle of $2^{\circ}$. Tri-stimulus color coordinates (CIELAB system) were used to measure the degree of lightness $\left(\mathrm{L}^{*}\right)$ which ranges from 0 (black) to 100 (white), redness (a) ranging from -60 (green) to +60 (red) and yellowness (b) ranging from blue $(-60)$ to yellow $(+60)$. The instrument was initially calibrated using a white ceramic 
Current Approaches in Science and Technology Research Vol. 14 Industrial Waste Whey as a Low-Cost, Efficient, and Environmentally Safe Disinfectant, with Potential Applications for Minimally

tile ( $\left.L^{*} 97.21 ; a^{*} 0.13 ; b^{*} 2.00\right)$. The measurement was performed by placing a piece of lettuce directly under the sensor and at least 30 measurements were done by treatment and day of evaluation, covering three different leaves coloration picked by naked eye selection (dark green, median green and light green).

\subsubsection{Sensory evaluation}

Evaluation of sensory quality of the samples, after washing with the sanitizing agents, along the ten days of storage, was performed by a panel of ten untrained members. Panelists were required to evaluate changes in visual quality (appearance/freshness), texture, flavor, off-odors, color (browning) and overall acceptability of samples. Samples were scored by an hedonic scale from 1 to 9 with descriptors anchored at both ends (dislike, not characteristic of the product and like very much, very characteristic of the product) to describe attributes considered. The limit of acceptance from the consumer's point of view is set to be 5 , and values below this point indicate unacceptable samples.

\subsubsection{Microbial analysis}

Enumeration of Aerobic Microorganisms at $30^{\circ} \mathrm{C}$ (AM), Psychrotrophic Microorganisms (PM) and Lactic Acid Bacteria (LAB) were performed in duplicate plates as previously described by Santos et al. [41]. Counts were performed for lettuce shreds before and after sanitizing treatments, to monitor microbial development during storage at 1,3,5, 7, 9 and 10 days in three independent trials.

\subsection{Statistical Analysis}

Statistical analysis was made by applying variance analysis, the one factor (ANOVA), and post-hoc multiple comparisons (Tukey test).

\section{RESULTS AND DISCUSSION}

\subsection{Longer Fermentation Periods are Important for the Highest Lactic Acid Production and the Lowest Sugar Content}

Although lactic acid production is of importance, the major aim of our research was to obtain a disinfecting agent with immediate application to spin-off as an easy, low-cost, technology. While most studies use short fermentation periods such as $24 \mathrm{~h}[33,39]$, in the present work we allowed the fermentation to last up to $120 \mathrm{~h}$. The metabolite profile obtained throughout fermentation period is graphed in Fig. 1, which shows the amounts of several metabolites: lactose, galactose, acetic and lactic acids, as well as the $\mathrm{pH}$ throughout the $120 \mathrm{~h}$. Results show that although the $\mathrm{pH}$ dropped from 6.6 to 3.9 during the first $24 \mathrm{~h}$ of fermentation, lactic acid production continued to increase through the $120 \mathrm{~h}$, supporting the need to use longer fermentation times, as opposed to the usual procedure in most studies. Lactic acid was the main acid detected, but acetic acid $\left(0.89 \mathrm{~g} \cdot \mathrm{L}^{-1}\right)$ was produced after $120 \mathrm{~h}$. Starting from $30 \mathrm{~g} \cdot \mathrm{L}^{-1}$ lactose in the unfermented whey, the starter led to a mass conversion rate of lactose into lactic acid of 0.56 , while residual lactose was $2.61 \mathrm{~g} \cdot \mathrm{L}^{-1}$. The yield of converting lactose into lactic acid was therefore higher in our work when compared to other works, such as Plessas et al. [45] who reported a 0.47 conversion rate. Also, the fact that lactose was reduced to concentrations lower than $3 \mathrm{~g} \cdot \mathrm{L}^{-1}$ makes it suitable to be used in food products as a disinfectant without the problems of lactose intolerance [46].

Hence, overall results show that our fermentation protocol has the potential to reduce the environmental impact of whey by reducing its organic content.

\subsection{Antibacterial Activity is also Dependent on the Length of Fermentation}

Although several works have already shown that fermented whey can be used as an antibacterial agent in minimally processed salads, being able to reduce overall microorganism growth $[8,40]$, most studies also use fermentation periods around 24 to $72 \mathrm{~h}[33,39]$. Since lactic acid production was 
Current Approaches in Science and Technology Research Vol. 14 Industrial Waste Whey as a Low-Cost, Efficient, and Environmentally Safe Disinfectant, with Potential Applications for Minimally

higher in longer fermentation periods, we set out to search the best timing along fermentation for higher antibacterial activity. Hence, whey samples were collected daily throughout the $120 \mathrm{~h}$, and firstly tested against reference Gram-positive Listeria monocytogenes 4b and Gram-negative Escherichia coli O157:H7, and MIC were determined for each day (Table 1). Results show that our fermented whey reduced the growth of both bacteria, from day 1 in Escherichia coli O157:H7 and from day 4 in $L$. monocytogenes $4 \mathrm{~b}$, concomitantly to the increase in lactic acid produced (Fig. 1), respectively, of approximately 5 and $15 \mathrm{~g} \cdot \mathrm{L}^{-1}$. However, more importantly, activities were significantly higher on the final day of fermentation, where MICs were more significantly reduced. Thus, our results indicate that fermentation periods longer than $72 \mathrm{~h}$ should be preferred in this type of study to obtain the best antibacterial activities.

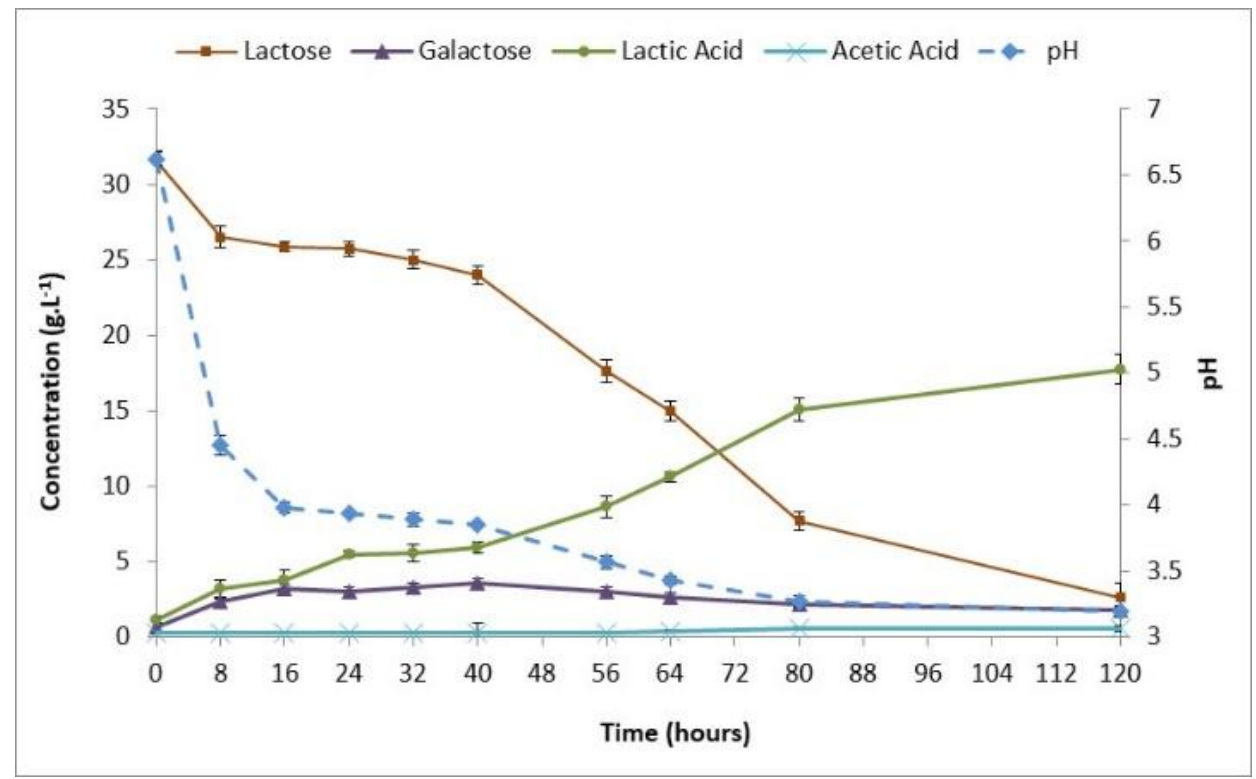

Fig. 1. Metabolite profile of whey during fermentation by mesophilic starter bacteria; Results reflect the average of three independent trials \pm standard deviation

Table 1. Minimum inhibitory concentrations (MIC) of fermented whey to control two selected bacterial strains*

\begin{tabular}{lll}
\hline Days of Fermentation & \multicolumn{2}{c}{ Strains } \\
\cline { 2 - 3 } & Listeria monocytogenes 4b (MIC) & Escherichia coli 0157:H7 (MIC) \\
\hline 1 & $\mathrm{NI}$ & 25.0 \\
2 & $\mathrm{NI}$ & 25.0 \\
3 & $\mathrm{NI}$ & 25.0 \\
4 & 25.0 & 25.0 \\
5 & 1.56 & 3.13 \\
\hline Note: ${ }^{*}, \mathrm{NI}=$ No inhibition observed. Figures are averages of three independent experiments, expressed in \% (V/V)
\end{tabular}

\subsection{Five Days-Fermented Whey Presents Dose-Dependent Antibacterial Activities and is Effective Against Several Bacterial Species}

Based on the results in Fig. 1 and Table 1, whey fermented for $120 \mathrm{~h}$ was selected to further analyze antibacterial activities towards thirteen pathogenic and spoilage strains, and results are presented in Fig. 2. Results show that growth inhibition was induced in all strains, either being Gram-negative or Gram-positive species, corroborating a broad range of antibacterial activity. Subsequently, $120 \mathrm{~h}$ whey samples were evaluated against $L$. monocytogenes and assessed at three different dilutions (Table 2) and compared to milk and non-fermented whey. Results show there was a dose-dependent effect in 
Current Approaches in Science and Technology Research Vol. 14 Industrial Waste Whey as a Low-Cost, Efficient, and Environmentally Safe Disinfectant, with Potential Applications for Minimally Processed Foodstuff

$120 \mathrm{~h}$ fermented whey, whereas neither milk nor unfermented whey exhibited an antibacterial effect ( $p$ $<0.05$ ) (Table 2).

\begin{tabular}{|c|c|c|c|c|}
\hline & \multicolumn{2}{|c|}{$\varnothing \mathrm{mm}$} & \multirow{3}{*}{ Bacillus_subtitlis } & \\
\hline & Test & + Control & & \\
\hline E. coli & $25.07 \pm 0.15$ & $26.17 \pm 0.12$ & & \\
\hline E. coli 0157 & $25.27 \pm 0.06$ & $25.00 \pm 0.10$ & & \\
\hline$S$. Goldcoast & $25.10 \pm 0.17$ & $18.10 \pm 0.20$ & Citrobacter_freundii & \\
\hline$S$. Thiphymurium & $22.43 \pm 0.15$ & $20.23 \pm 0.12$ & & \\
\hline Pantoa agglomerans & $31.23 \pm 0.21$ & $26.07 \pm 0.15$ & & \\
\hline Citrobacter freundii & $30.10 \pm 0.17$ & $25.20 \pm 0.30$ & $\begin{array}{l}\text { Pseudomonas } \\
\text { fluorecens }\end{array}$ & \\
\hline P. aeruginosa & $25.10 \pm 0.17$ & $23.17 \pm 0.25$ & & \\
\hline P. fluorenscens & $33.97 \pm 0.21$ & NI & & \\
\hline L. monocytogenes & $31.20 \pm 0.17$ & $30.13 \pm 0.21$ & Escherichia coli & \\
\hline L. innocua & $23.23 \pm 0.23$ & $21.97 \pm 0.06$ & & 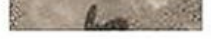 \\
\hline S. aureus & $25.10 \pm 0.17$ & $30.40 \pm 0.26$ & & \\
\hline B. cereus & $31.47 \pm 0.21$ & $35.13 \pm 0.06$ & $\begin{array}{l}\text { Salmonella } \\
\text { thiphymurium }\end{array}$ & \\
\hline B. subtilis & $22.10 \pm 0.10$ & $17.10 \pm 0.30$ & & \\
\hline
\end{tabular}

Fig. 2. Inhibition halos of different bacteria exposed to $120 \mathrm{~h}$ fermented whey; Chlorine was used as a positive control; Results are the average of three replicates \pm standard deviation Note: $\mathrm{NI}=$ No inhibition observed

Table 2. Halos of inhibition of $L$. monocytogenes growth exposed to $120 \mathrm{~h}$ fermented whey, milk, or non-fermented whey diluted in water

\begin{tabular}{|c|c|c|c|}
\hline \multicolumn{4}{|c|}{ Inhibition Halo (mm) } \\
\hline Dilutions in water (v/v) & Milk & Non-Fermented whey & Fermented whey ** \\
\hline $25 \%$ & 0 & 0 & $20.70 \pm 0.05^{+}$ \\
\hline $50 \%$ & 0 & 0 & $24.70 \pm 0.05$ * \\
\hline $100 \%$ & 0 & 0 & $31.20 \pm 0.17 \#$ \\
\hline
\end{tabular}

\subsection{Industrial Whey is an Effective Disinfecting Agent When Applied to Lettuce, with Better or Similar Results When Compared Chlorine}

Because we aimed to test our $120 \mathrm{~h}$ fermented whey in a more realistic manner, we set out to determine its efficacy as a lettuce disinfectant, testing quality indices such as texture and color, including its evaluation by a sensory panel, and also assessing its microbiological quality.

\subsection{1 $\mathrm{O}_{2}$ and $\mathrm{CO}_{2}$}

Table 3 summarizes the monitoring of the $\mathrm{O}_{2}$ contents and production of $\mathrm{CO}_{2}$ in the lettuce bags over the 10 days of cold storage. While oxygen was practically kept constant around $19 \%$ for the reference 
Current Approaches in Science and Technology Research Vol. 14 Industrial Waste Whey as a Low-Cost, Efficient, and Environmentally Safe Disinfectant, with Potential Applications for Minimally

samples treated with water, for shredded lettuce sanitized with fermented whey, a reduction from 19 to $18 \%$ on the first day was observed, and then it remained practically constant. With chlorine, the reduction continued until the third day to values around $16 \%$.

Table 3. Oxygen and carbon dioxide measurements for packed sanitized shredded lettuce with different sanitizer treatments, over 10 days in cold storage

\begin{tabular}{lllllll}
\hline Days of & \multicolumn{3}{c}{$\mathbf{O}_{\mathbf{2}}(\%)$} & & \multicolumn{3}{c}{$\mathbf{C O}_{\mathbf{2}}(\%)$} \\
Storage & Water & Chlorine & Whey & Water & Chlorine & Whey \\
\hline Day 0 & $19.79 \pm 0.41$ & $19.9 \pm 0.61$ & $19.4 \pm 0.50$ & $0.01 \pm 0.04$ & $0.00 \pm 0.00$ & $0.02 \pm 0.07$ \\
Day 1 & $19.31 \pm 0.34$ & $18.5 \pm 0.86$ & $18.0 \pm 0.71$ & $0.06 \pm 0.09$ & $0.43 \pm 0.25$ & $0.60 \pm 0.32$ \\
Day 3 & $19.44 \pm 0.55$ & $16.2 \pm 2.31$ & $17.5 \pm 1.69$ & $0.23 \pm 0.32$ & $0.95 \pm 0.78$ & $0.46 \pm 0.49$ \\
Day 5 & $19.22 \pm 0.71$ & $17.1 \pm 1.68$ & $17.7 \pm 1.90$ & $0.57 \pm 0.46$ & $0.96 \pm 0.80$ & $0.56 \pm 0.61$ \\
Day 7 & $19.02 \pm 0.81$ & $17.5 \pm 1.80$ & $17.8 \pm 1.42$ & $0.56 \pm 0.47$ & $0.93 \pm 0.83$ & $0.63 \pm 0.58$ \\
Day 9 & $18.97 \pm 0.91$ & $16.5 \pm 1.86$ & $17.8 \pm 2.00$ & $0.64 \pm 0.54$ & $1.33 \pm 0.70$ & $0.66 \pm 1.01$ \\
Day 10 & $19.20 \pm 0.94$ & $16.7 \pm 1.18$ & $17.3 \pm 2.17$ & $0.61 \pm 0.57$ & $1.33 \pm 0.52$ & $0.78 \pm 0.78$ \\
\hline
\end{tabular}

For the $\mathrm{CO}_{2}$ production, more pronounced differences are shown, becoming apparent that the bags treated with chlorine showed a higher reduction in $\mathrm{O}_{2}$ levels and a larger production of $\mathrm{CO}_{2}$ compared to the reference and whey treated bags. Consumption of $\mathrm{O}_{2}$ and production of $\mathrm{CO}_{2}$ could come from the respiration of the lettuce leaves and $\mathrm{AM}$, as well as further production of $\mathrm{CO}_{2}$ from anaerobic fermenting microorganisms. Although results suggest that water- and whey-treated samples have lower biological activity, the higher changes detected in the samples treated with chlorine could be due to the response of the lettuce cell leaves to the chemical stress of the chlorinated compounds.

\section{$3.4 .2 \mathrm{pH}$}

From Fig. 3, we can observe that there are no major differences between the $\mathrm{pH}$ of the different treatments, with a tendency for a slight increase along the 10-day period. The reference, i.e., lettuce washed with distilled water, is the sample where the increase of $\mathrm{pH}$ is significantly $(\mathrm{p}<0.05$ i.e. $\mathrm{p}=8.8$ $\times 10^{-6}$ ) higher, from 6.16 to 7.00 , but still less than a unit of variation for a storage period of ten days. Martin-Diana et al. [8] reported a similar increase in $\mathrm{pH}$ in a study with lettuce and carrots and stated that this was a good index for the potential quality maintenance of the products.

According to Beuchat [47], vegetable products retain adequate quality in a $\mathrm{pH}$ range of 5-6.5. Our results show that samples treated with whey exceeded this value (6.57) only on day 9 , and the samples treated with chlorine exceeded it on day 7 (6.75).

\subsubsection{Texture}

Texture is a major quality parameter, and together with color they are crucial for consumer acceptance. Texture measurements evaluated two parameters: resistance to puncture as a force in $\mathrm{N}$, and deformation at rupture in length $(\mathrm{mm})$, generally described as firmness and brittleness (the lower the deformation, the more brittle the material is), respectively. Results are shown in Fig. 4a,b. As seen in Fig. 4a, the firmness of the lettuce shreds was not substantially affected by any of the treatment and variation within 10 days of storage was quite small. As observed with the $\mathrm{pH}$ variation, the reference treatment with water is where the highest difference is found- $74 \mathrm{mN}$, which is significantly $(p=2.2 \times$ $\left.10^{-6}\right)$ less firm, and $0.177 \mathrm{~mm}$ which is less brittle $(p=0.0027)$ after 10 days in cold storage, i.e. a reduction of $12 \%$ in firmness and $7 \%$ in brittleness, whereas with whey there was a significant increase in firmness of $69 \mathrm{mN}\left(p=8.2 \times 10^{-6}\right)$, corresponding to a $10 \%$ increment and no significant variation on brittleness $(p>0.05)$, which is due to the calcium ions present in the whey solution that might reinforce the walls of the lettuce cells. 


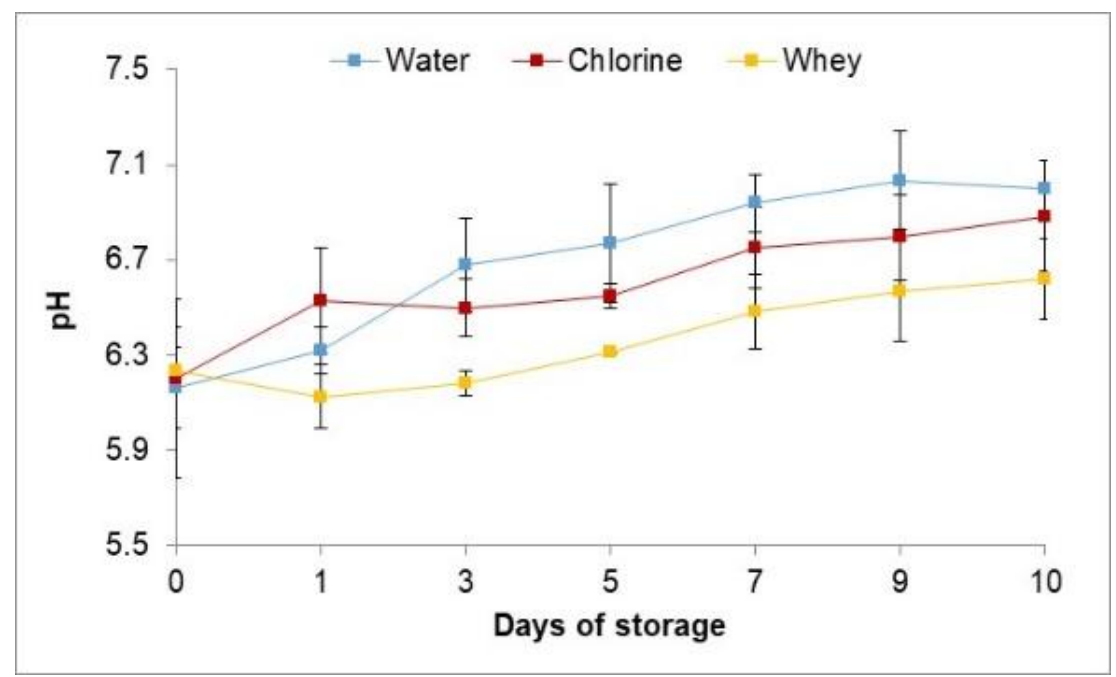

Fig. 3. The pH measurements of the lettuce after sanitizer treatments, over 10 days in cold storage; Results represent the average of at least three replicate experiments $(n=3) \pm S D$

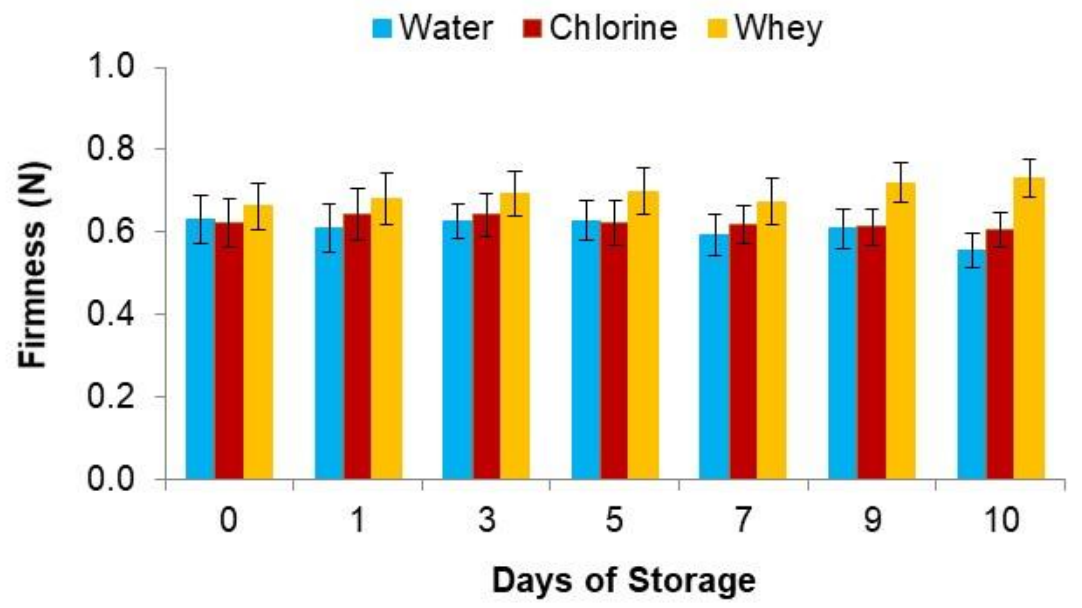

(a)

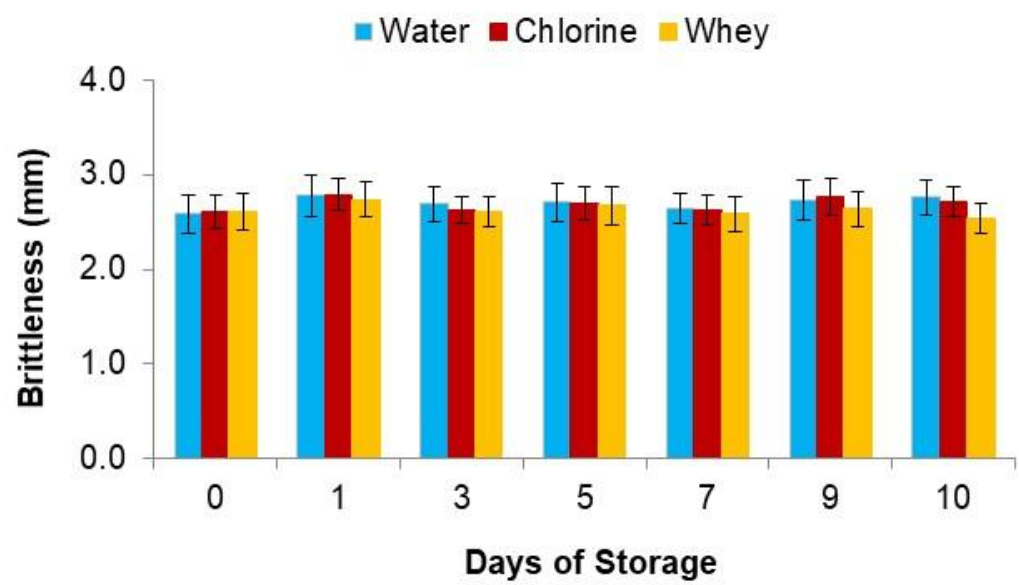

(b)

Fig. 4. Firmness (a) and Brittleness (b) of the lettuce after sanitizer treatments, over 10 days in cold storage; Results represent the average of at least three replicate experiments $(n=3) \pm$ SD 
Current Approaches in Science and Technology Research Vol. 14 Industrial Waste Whey as a Low-Cost, Efficient, and Environmentally Safe Disinfectant, with Potential Applications for Minimally Processed Foodstuff

\subsubsection{Color measurement}

In Table 4, the lightness $L^{*}$ color parameter for shreds of mid-tone, i.e., median green, can be seen. These results are too scattered to be able to differentiate between sanitizing treatments. The same was observed for the other color coordinates $a^{*}$ and $b^{*}$. Although 30 shots were taken for each measurement and standard deviations are not high, the chances of taking shreds from different color groups are high and conclusive results cannot be drawn from these experiments. Nevertheless, it can be said that color was not dramatically affected by all treatments.

\subsubsection{Sensory evaluation}

From the sensory evaluation, one can see the resulting spider diagrams for chlorine and whey treatments in Fig. 5a and Fig. 5b, respectively. Therefore, from the spider diagrams, one can see that all the attributes were highly scored, with all above the midpoint 5 , over the 10 days of cold storage.

To compare the two treatments, overall acceptability was chosen to represent the sensory results, and in Fig. 6 it can be seen that there are two major plateaus. The first showed top scores until day 5, and the second with scores around 6 from 7 to the 10th day of cold storage, probably related to the scores obtained for off-odors and flavor. From these results, no differences can be seen for the two treatments, with whey or with chlorine.

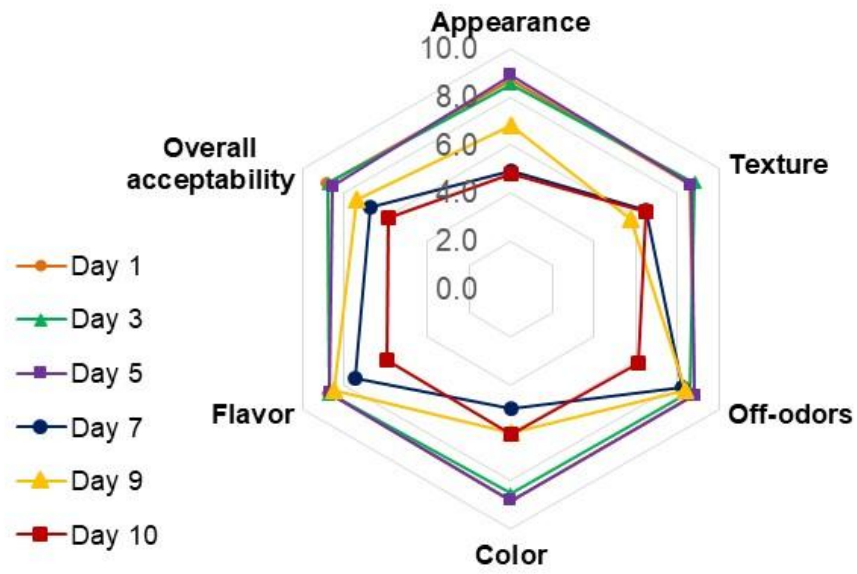

(a)

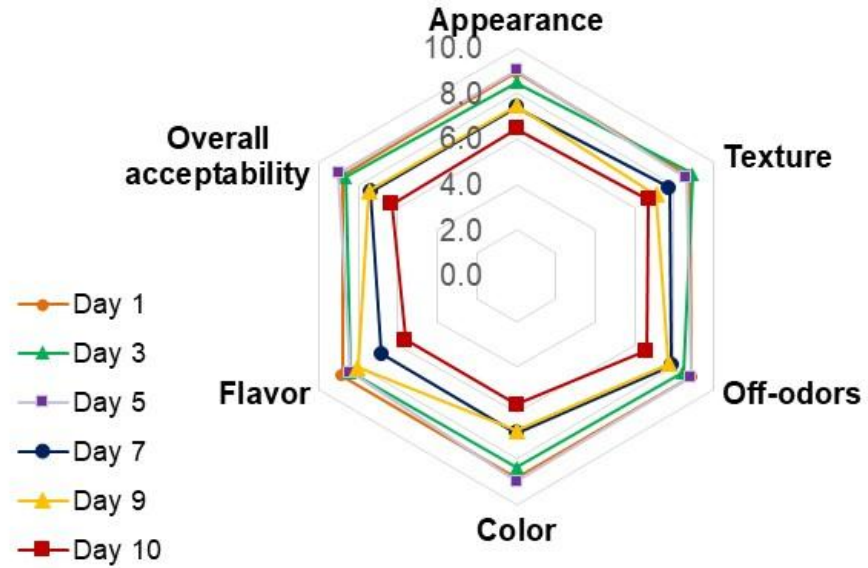

(b)

Fig. 5. Sensory scores of the lettuce treated with chlorine solution (a) and Fermented whey (b) over 10 days in cold storage. Results represent the average of at least three replicate experiments $(n=3) \pm S D$ 

Current Approaches in Science and Technology Research Vol. 14
Industrial Waste Whey as a Low-Cost, Efficient, and Environmentally Safe Disinfectant, with Potential Applications for Minimally
Processed Foodstuff

Table 4. Lightness $\left(\mathrm{L}^{*}\right)$ color parameter of the lettuce after sanitizer treatments, over 10 days in cold storage; Results represent the average of at least three replicate experiments $(n=3) \pm S D$

\begin{tabular}{|c|c|c|c|c|c|c|c|c|c|}
\hline \multirow[t]{2}{*}{ Days Storage } & \multicolumn{3}{|c|}{ Water } & \multicolumn{3}{|c|}{ Chlorine solution } & \multicolumn{3}{|c|}{ Fermented whey solution } \\
\hline & $\mathbf{L}^{*}$ & $\mathbf{a}^{*}$ & $\mathbf{b}^{\star}$ & $\mathbf{L}^{*}$ & $\mathbf{a}^{*}$ & $\mathbf{b}^{\star}$ & $\mathbf{L}^{*}$ & $\mathbf{a}^{\star}$ & $\mathbf{b}^{\star}$ \\
\hline 0 & $72.0 \pm 4.4$ & $-20.9 \pm 1.4$ & $39.0 \pm 1.1$ & $97.6 \pm 2.4$ & $-19.8 \pm 1.2$ & $37.2 \pm 0.9$ & $72.1 \pm 1.7$ & $-21.3 \pm 0.9$ & $38.3 \pm 1.7$ \\
\hline 1 & $70.2 \pm 3.3$ & $-20.8 \pm 2.4$ & $33.1 \pm 1.2$ & $72.7 \pm 3.2$ & $-20.4 \pm 0.9$ & $36.7 \pm 1.0$ & $103.3 \pm 2.8$ & $-21.3 \pm 0.6$ & $40.9 \pm 2.5$ \\
\hline 3 & $71.6 \pm 3.7$ & $-17.3 \pm 1.4$ & $33.1 \pm 1.9$ & $69.2 \pm 3.4$ & $-20.7 \pm 0.9$ & $39.3 \pm 2.5$ & $107.1 \pm 3.1$ & $-20.9 \pm 0.9$ & $37.8 \pm 2.2$ \\
\hline 5 & $101.8 \pm 2.3$ & $3.8 \pm 1.3$ & $2.4 \pm 1.8$ & $100.5 \pm 1.5$ & $-19.2 \pm 0.8$ & $34.3 \pm 1.3$ & $61.5 \pm 3.3$ & $-19.5 \pm 1.3$ & $36.3 \pm 2.3$ \\
\hline 7 & $74.5 \pm 2.9$ & $-19.1 \pm 1.4$ & $36.1 \pm 1.9$ & $95.2 \pm 1.9$ & $-10.8 \pm 1.0$ & $17.8 \pm 2.3$ & $64.9 \pm 2.2$ & $-20.2 \pm 0.8$ & $37.4 \pm 2.2$ \\
\hline 9 & $94.2 \pm 3.8$ & $-19.4 \pm 1.7$ & $39.7 \pm 2.7$ & $98.5 \pm 1.8$ & $-20.1 \pm 1.5$ & $35.2 \pm 2.7$ & $95.0 \pm 2.5$ & $-19.6 \pm 1.5$ & $37.9 \pm 2.3$ \\
\hline 10 & $97.1 \pm 4.0$ & $-19.0 \pm 1.6$ & $36.5 \pm 1.7$ & $105.6 \pm 3.3$ & $-16.2 \pm 1.6$ & $35.8 \pm 1.9$ & $93.8 \pm 3.3$ & $-19.8 \pm 1.6$ & $39.9 \pm 2.6$ \\
\hline
\end{tabular}




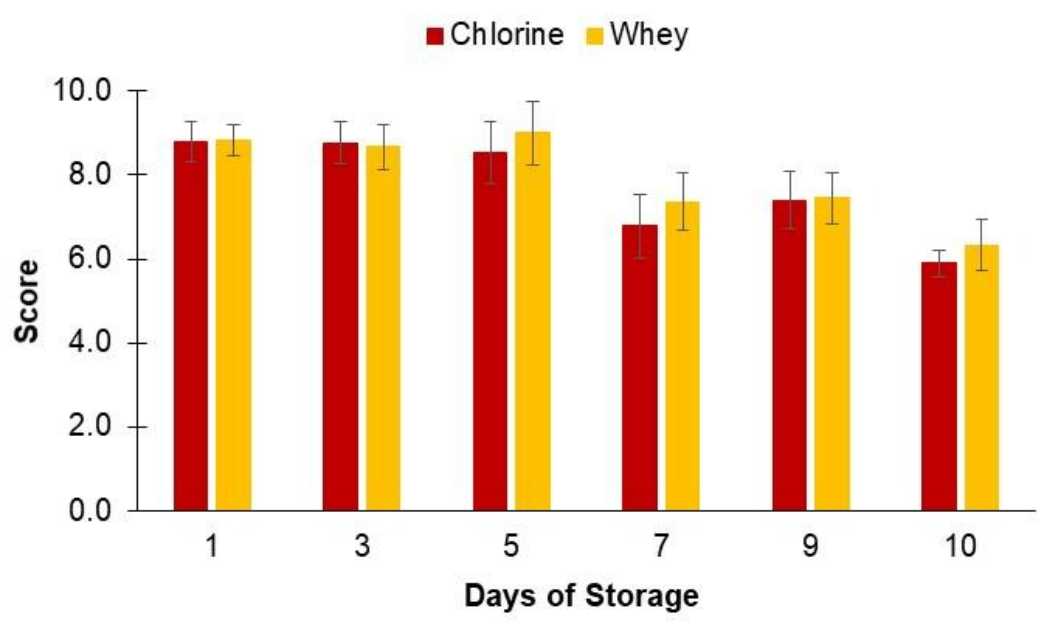

Fig. 6. Overall acceptability of the lettuce treated with fermented whey and chlorine over 10 days in cold storage. Results represent the average of at least three replicate experiments $(n=3) \pm$ SD

\subsubsection{Microbial markers}

\subsubsection{Aerobic microorganisms at $30^{\circ} \mathrm{C}$}

Enumeration of $\mathrm{AM}$ (aerobic microorganisms at $30^{\circ} \mathrm{C}$ ) is an indicator of quality and gives an estimate of total viable populations, both endogenous and contaminant microbiota, since microorganisms are inevitably introduced during manipulations [48]. However, in general, the initial contamination of vegetables reflects the microbiota environment in which they were grown $[49,50]$. Before treatment (day 0 ), the initial AM was $6.10 \mathrm{log} \mathrm{cfu} \cdot \mathrm{g}^{-1}$. Other works have found similar results in whole vegetables $[28,51,52]$. As can be observed in Fig. 7a, AM counts sharply decreased after all treatments $(p<$ $0.05)$. Throughout the storage, samples treated with whey always presented a significantly lower AM count $(p<0.001)$ when compared to water and chlorine, independent of time $(p<0.001)$. This is a strong indication of the effectiveness of fermented whey as an alternative disinfectant.

\subsubsection{Psychrotrophic microorganisms}

Similarly to AM, psychrotrophic microorganisms $(P M)$ counts were significantly reduced $(p<0.05)$ in all treatments at day 1 (Fig. $7 \mathrm{~b})$. Also, the highest count reduction $(p<0.001)$ to $2.20 \log \mathrm{cfu} \cdot \mathrm{g}^{-1} \mathrm{occurred}$ in samples treated with whey. With chlorine, the count reduction found was $1.13 \mathrm{log} \mathrm{cfu} \cdot \mathrm{g}^{-1}$. In the case of the PM, both for the lettuce treated with whey as well as with chlorine, after 5 days in cold storage, there were no significant differences between both treatments in respect to these counts.

\subsubsection{Lactic acid bacteria}

Because whey contains naturally high counts of LAB (in this case $10^{7} \mathrm{cfu} \cdot \mathrm{g}^{-1}$ ), which could induce a higher bacterial load into the product, we investigated the evolution of LAB counts in all treatments throughout cold storage time, and results are presented in Fig. 7c. As can be seen, although on day 1 there was a significant difference between LAB counts in all treatments, from day 3 onward, the presence of live LAB from fermented whey did not confer a significant difference $(p>0.05)$ when compared to chlorine and water treatments. This type of bacteria is normally present in MP vegetables in loads from 2 to $6 \mathrm{log} \mathrm{cfu} \cdot \mathrm{g}^{-1}$ (Fig. 7c; at day 0 , our reference sample was around $3.5 \mathrm{log} \mathrm{cfu} \cdot \mathrm{g}^{-1}$ ), so $\mathrm{LAB}$ counts ended up being similar in all treatments tested, meaning that the introduction of $L A B$ from whey would not pose any noticeable difference to the final product. Furthermore, it has been shown that the presence of these LAB could have a positive antimicrobial effect in lettuce and apple taste [35]. Additionally, the presence of lactic acid, antibacterial peptides, and low pH are contributive factors for the inhibitory effects of whey [53-55]. 
Current Approaches in Science and Technology Research Vol. 14 Industrial Waste Whey as a Low-Cost, Efficient, and Environmentally Safe Disinfectant, with Potential Applications for Minimally Processed Foodstuff

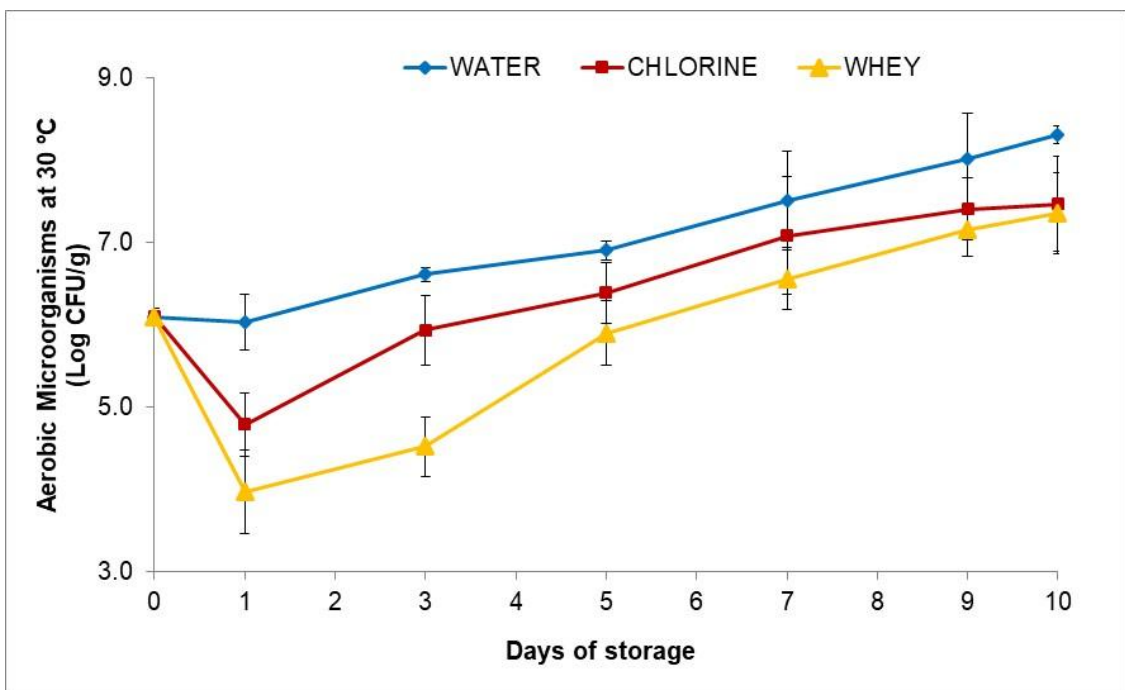

(a)

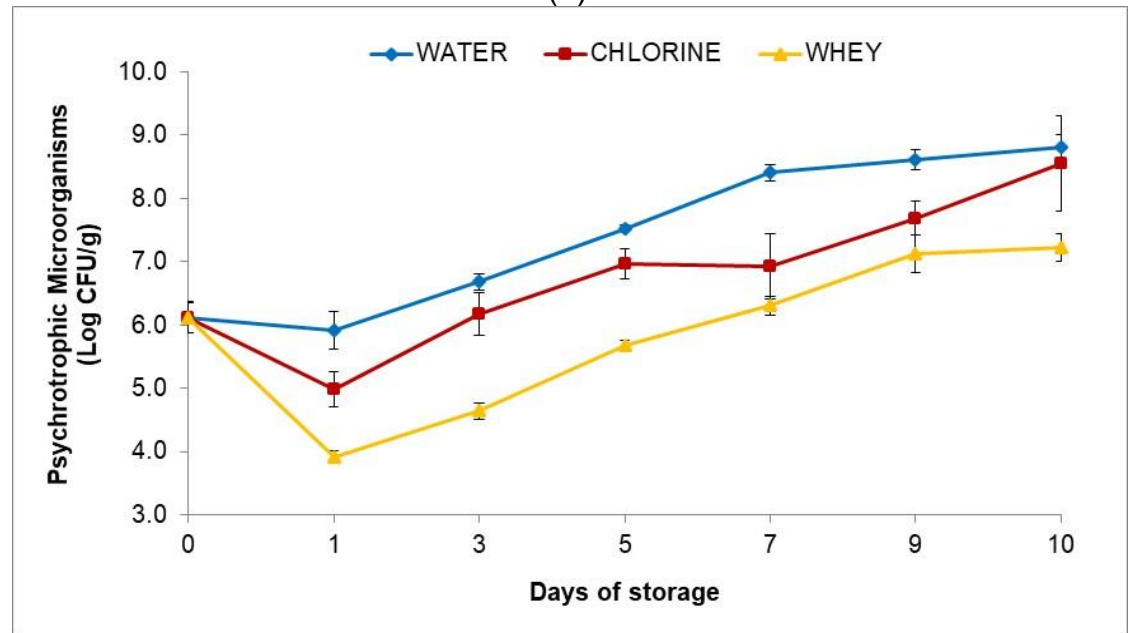

(b)

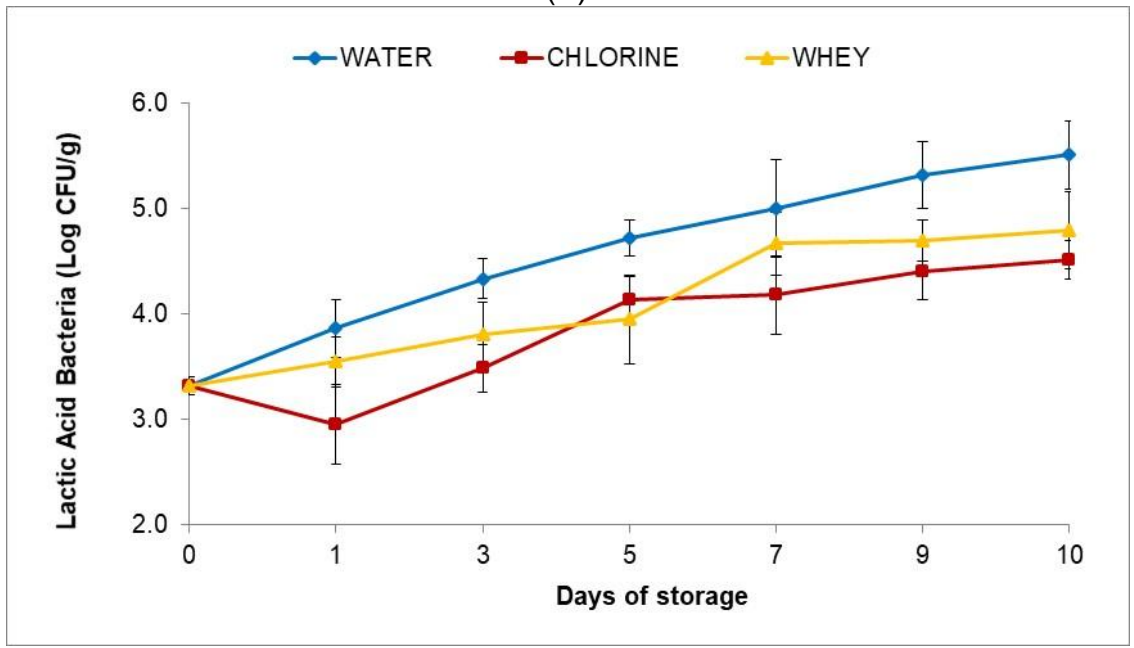

(c)

Fig. 7. Packed shredded lettuce: effect of sanitation on shredded lettuce Aerobic Microorganisms (a), Psychotropic Microorganisms (b), and Lactic Acid Bacteria (c) over 10 days in cold storage. Results represent the average of at least three replicate experiments

$$
(n=3) \pm S D
$$




\section{CONCLUSION}

In conclusion, our overall results showed that the established fermentation for industrial whey has the potential to be a low-cost, scalable process to reduce the environmental impact of whey by reducing its organic content, and holds strong potential as an effective disinfecting agent when applied to lettuce, with better or similar results when compared to a $110 \mathrm{ppm}$ chlorine solution. Also importantly, it did not alter the quality parameters of the shredded loose-leaf lettuce, which is highly prone to decay. Color was not substantially affected, and panelists were not able to discriminate from chlorine treatments. Furthermore, lettuce shreds treated with fermented whey showed a slight reinforcement within the cold storage time. Overall, these results not only suggest that fermented whey is indeed as effective as chlorine, but also corroborates that our technology of whey fermentation is effective in maintaining the quality of lettuce throughout storage.

\section{ACKNOWLEDGEMENTS}

The authors would like to thank Sara Bernardes Silva, Technical Director of Indústria de Laticínios SA, Portugal, for kindly providing the cheese whey used in this work; Rosália Furtado, Maria João Barreira, Anabela Coelho, from the Food Microbiology Laboratory of Instituto Nacional de Saúde Dr. Ricardo Jorge (INSA) for providing some strains used in this work and for technical assistance; Isabel Barroso and Lidia Joaquim from Universidade Lusófona de Humanidades e Tecnologias (ULHT), for technical assistance. And to acknowledge financial support from FCT (Foundation for Science and Technology, Portugal) through the research unit UID/4129/2020 (LEAF) and publication costs.

\section{COMPETING INTERESTS}

Authors have declared that no competing interests exist.

\section{REFERENCES}

1. Ryan MP. The biotechnological potential of whey. Rev. Environ. Sci. Biotechnol. 2016;479-498. DOI: $10.1007 / \mathrm{s} 11157-016-9402-1$.

2. Prazeres A, Carvalho F, Rivas J. Cheese whey management: A review. J. Environ. Manag. 2012;110:48-68.

DOI: 10.1016/j.jenvman.2012.05.018

3. Carvalho F, Prazeres A, Rivas J. Cheese whey wastewater: Characterization and treatment. Sci. Total Environ. 2013;445:385-396.

DOI: $10.1016 /$ j.scitotenv.2012.12.038

4. Murari CS, Moraes DC, Bueno GF, Del Bianchi VL. Avaliação da redução na poluição dos laticínios, a partir da fermentação do soro de leite em etanol pela levedura Kluyveromyces Marxianus 229. Revista do Instituto de Laticínios Cândido Tostes, Juiz de Fora. 2013;68:42-50. DOI: $10.5935 / 2238-6416.20130034$

5. Lievore P, Simões DRS, Silva KM, Drunkler NL, Barana AC, Nogueira A, et al. Chemical characterisation and application of acid whey in fermented milk. J. Food Sci. Technol. 2015;52:2083-2092.

DOI: $10.1007 /$ s13197-013-1244-z

6. Smithers G. Whey and whey proteins_From gutter-to-gold. Int. Dairy J. 2008;18:695-704.

DOI: 10.1016/j.idairyj.2008.03.008

7. Brandelli A, Daroit DJ, Corrêa APF. Whey as a source of peptides with remarkable biological activities. Food Res. Int. 2015;73:149-161.

DOI: 10.1016/j.foodres.2015.01.016

8. Martin-Diana A, Rico D, Frias J, Mulcahy J. Whey permeate as a bio-preservative for shelf life maintenance. Innov. Food Sci. Emerg. 2006;7:112-123.

DOI: 10.1016/j.ifset.2005.08.002

9. Panesar P, Kennedy J, Gandhi D, Bunko K. Bioutilisation of whey for lactic acid production. Food Chem. 2007;105:1-14.

DOI: 10.1016/j.foodchem.2007.03.035 
10. Rico D, Martín-Diana A, Barat J, Barry-Ryan C. Extending and measuring the quality of fresh-cut fruit and vegetables: A review. Trends Food Sci. Technol. 2007;18:373-386.

DOI: 10.1016/j.tifs.2007.03.011.

11. Rizello CG, Losito I, Gobbetti M, Carbonara T, Bari MD, Zambonin PG. Antibacterial Activities of Peptides from the Water-Soluble Extracts of Italian Cheese Varieties. J. Dairy Sci. 2005;88:2348-2360.

DOI: 10.3168/jds.S0022-0302(05)72913-1

12. Almaas H, Eriksen E, Sekse C, Comi I, Flengsrud R, Holm H, et al. Antibacterial peptides derived from caprine whey proteins, by digestion with human gastrointestinal juice. Br. J. Nutr. 2011;106:896-905.

DOI: $10.1017 / S 0007114511001085$

13. Medeiros GV, Queiroga RE, Costa WA, Gadelha CA, Lacerda RR, Lacerda JG, et al. Proteomic of goat milk whey and its bacteriostatic and antitumour potential. Int. J. Biol. Macromol. 2018;113:116-123.

DOI: 10.1016/j.ijbiomac.2018.01.200

14. Hafeez Z, Cakir-Kiefer C, Roux E, Perrin C, Miclo L, Dary-Mourot A. Strategies of producing bioactive peptides from milk proteins to functionalize fermented milk products. Food Res. Int. 2014;63:71-80.

DOI: $10.1016 /$ j.foodres.2014.06.002

15. Théolier J, Hammami R, Labelle P, Fliss I, Jean J. Isolation and identification of antimicrobial peptides derived by peptic cleavage of whey protein isolate. J. Funct. Foods. 2013;5:706-714.

DOI: 10.1016/j.jff.2013.01.014

16. Dullius A, Goettertb MI, Souza CV. Whey protein hydrolysates as a source of bioactive peptides for functional foods - Biotechnological facilitation of industrial scale-up. J. Funct. Foods. 2018;42:58-74.

DOI: 10.1016/j.jff.2017.12.063

17. Murray K, Fan Wu F, John Shi J, Sophia Jun Xue, Warriner SJK. Challenges in the microbiological food safety of fresh produce: Limitations of post-harvest washing and the need for alternative interventions. Food Qual. Saf. 2017;1:289-301.

DOI: $10.1093 /$ fqsafe/fyx027

18. Callejón RM, Rodríguez-Naranjo MI, Ubeda C, Hornedo-Ortega R, Garcia-Parrilla MC, Troncoso AM. Reported foodborne outbreaks due to fresh produce in the United States and European Union: Trends and causes. Foodborne Pathog. Dis. 2015;12:32-38.

DOI: 10.1089/fpd.2014.1821

19. Charlier C, Goffinet F, Azria A, Leclercq A, Lecuit M. Inadequate management of pregnancyassociated listeriosis: Lessons from four case reports. Clin. Microbiol. Infec. 2014;20:246-249. DOI: $10.1111 / 1469-0691.12281$

20. Francis GA, Thomas C, O'Breirne D. Isolation and pulsed-field gel electrophoresis typing of Listeria monocytogenes from modified atmosphere packaged fresh-cut vegetables collected in Ireland. J. Food Protect. 2006;69:2524-2558.

21. Gombas D, Chen Y, Clavero R, Scott V. Survey of Listeria monocytogenes in Ready-to-Eat Foods. J. Food Protect. 2003;66:559-569.

22. Lianou A, Sofos JN. A review of the incidence and transmission of Listeria monocytogenes in ready-to-eat products in retail and food service environments. J. Food Protect. 2007;70:21722198.

23. World Health Organization \& Food and Agriculture Organization of the United Nations. 2008. Microbiological hazards in fresh leafy vegetables and herbs: Meeting report. World Health Organization. (Acessed on 22 November 2018).

Available:https://apps.who.int/iris/handle/10665/44031

24. Scientific Committee on Food. Risk Profile on the Microbiology Contamination of Fruits and Vegetables Eaten Raw. Report of the Scientific Commission on Food, European Commission on Health and Consumer Protection Directorate-General; 2002.

Available:https://ec.europa.eu/food/sites/food/files/safety/docs/sci-com_scf_out125_en.pdf (Accessed on 22 November 2018).

25. Meireles A, Giaouris E, Simões M. Alternative disinfection methods to chlorine for use in the fresh-cut industry. Food Res. Int. 2016;82:71-85.

DOI: 10.1016/j.foodres.2016.01.021 
26. Francis GA, Gallone A, Nychas GJ, Sofos JN, Colelli G, Amodio ML, et al. Factors affecting quality and safety of fresh-cut produce. Crit. Rev. Food Sci. Nutr. 2012;52:595-610.

DOI: 10.1080/10408398.2010.503685

27. Warriner K, Namvar A. Recent advances in fresh produce post-harvest decontamination technologies to enhance microbiological safety. Stewart Postharvest Rev. 2013;9:1-8.

DOI: 10.2212/spr.2013.1.3

28. Santos MI, Cavaco A, Gouveia J, Novais MR, Nogueira PJ, Pedroso L, Ferreira MASS. Evaluation of minimally processed salads commercialized in Portugal. Food Control. 2012;23:275-281.

DOI: 10.1016/j.foodcont.2011.06.022

29. Gil MI, Selma MV, López-Gálvez F, Allende A. Fresh-cut product sanitation and wash water disinfection: Problems and solutions. Int. J. Food Microbiol. 2009;134:37-45.

DOI: 10.1016/j.ijfoodmicro.2009.05.021.

30. Akbas MY, Ölmez H. Inactivation of Escherichia coli and Listeria monocytogenes on iceberg lettuce by dip wash treatments with organic acids. Lett. Appl. Microbiol. 2007;44:619-624.

DOI: 10.1111/j.1472-765X.2007.02127.x

31. Beuchat LR, Adler BB, Lang MM. Efficacy of chlorine and a peroxyacetic acid sanitizer in killing Listeria monocytogenes on iceberg and romaine lettuce using simulated commercial processing conditions. J. Food Protect. 2004;67:1238-1242.

32. Tian J, Ban $\mathrm{X}$, Zeng $\mathrm{H}$, Huang $\mathrm{B}, \mathrm{He} \mathrm{J}$, Wang $\mathrm{Y}$. In vitro and in vivo activity of essential oil from dill (Anethum graveolens L.) against fungal spoilage of cherry tomatoes. Food Control. $2011 ; 22: 1992-1999$.

DOI: 10.1016/j.foodcont.2011.05.018.

33. Guha A, Banerjee S, Bera D. Production of lactic acid from sweet meat industry waste by Lactobacillus delbruki. Int. J. Res. Eng. Technol. 2013;2:630-634.

DOI: 10.15623/ijret.2013.0204039

34. Siroli L, Patrignani F, Diana I, Serrazanetti DI, Gardini F, Lanciotti R. Innovative strategies based on the use of bio-control agents to improve the safety, shelf-life and quality of minimally processed fruits and vegetables. Trends Food Sci. Technol. 2015;46:302-310.

DOI: 10.1016/j.tifs.2015.04.014

35. Trias R, Bañeras L, Badosa E, Montesinos E. Bioprotection of Golden Delicious apples and Iceberg lettuce against foodborne bacterial pathogens by lactic acid bacteria. Int. J. Food Microbiol. 2008;123:50-60.

DOI: 10.1016/j.ijfoodmicro.2007.11.065

36. Bjorkroth J, Koort J. Lactic acid bacteria: Taxonomy and Biodiversity. In Encyclopedia of Dairy Sciences, 2nd ed.; Fuquay JW, Fox PF, McSweeney PLH, Eds.; Academic Press: London, UK. 2011;3:45-48.

37. Madureira AR, Soares JC, Amorim M, Tavares T, Gomes AM, Pintado MM, Malcata FX. Bioactivity of probiotic whey cheese: Characterization of the content of peptides and organic acids. J. Sci. Food Agric. 2013;93:1458-1465.

DOI: $10.1002 /$ jsfa.5915

38. Zacharof $M$, Lovitt $R$. Bacteriocins produced by lactic acid bacteria a review article. APCBEE Proc. 2012;2:50-56.

DOI: 10.1016/j.apcbee.2012.06.010.

39. Panesar PS. Kumari S, Panesar R. Potential applications of immobilized $\beta$-galactosidase in food processing industries. Enzyme Res. 2010;2010:473137.

DOI: $10.4061 / 2010 / 473137$

40. Santos MIS, Lima AI, Monteiro SAVS, Ferreira RMSB, Pedroso L, Sousa I, Ferreira MASS. Preliminary study on the effect of fermented cheese whey on Listeria monocytogenes, Escherichia coli O157:H7 and Salmonella Goldcoast populations inoculated onto fresh organic lettuce. Foodborne Pathog. Dis. 2016;13:423-427.

DOI: $10.1089 / f p d .2015 .2079$

41. Santos MIS, Martins SR, Pedroso L, Sousa I, Ferreira MASS. Potential bio-activity of whey fermented extract as sanitizer of organic grown lettuce. Food Control. 2015;50:477-481.

DOI: 10.1016/j.foodcont.2014.09.032. 
42. Gottlieb CT, Thomsen LE, Ingmer H. Antimicrobial peptides effectively kill a broad spectrum of Listeria monocytogenes and Staphylococcus aureus strains independently of origin, sub-type, or virulence factor expression. BMC Microbiol. 2008;8:205.

DOI: 10.1186/1471-2180-8-205

43. Bouhdid S, Abrini J, Amensour M, Zhiri A, Espuny MJ, Manresa A. Functional and ultrastructural changes in Pseudomonas aeruginosa and Staphylococcus aureus cells induced by Cinnamomum verum essential oil. J. Appl. Microbiol. 2010;109:1139-1149.

DOI: $10.1111 / \mathrm{j} .1365-2672.2010 .04740 . x$

44. Pintado CMBS, Ferreira MASS, Sousa I. Properties of whey-protein based films containing organic acids and nisin to control Listeria monocytogenes. J. Food Prot. 2009;72:1891-1896.

45. Plessas S, Bosnea L, Psarianos C, Koutinas A, Marchant R, Banat IM. Lactic acid production by mixed cultures of Kluyveromyces marxianus, Lactobacillus delbrueckii ssp. bulgaricus and Lactobacillus helveticus. Bioresour. Technol. 2008;99:5951-5955.

DOI: 10.1016/j.biortech.2007.10.039

46. European Food Safety Authority. Scientific opinion on lactose thresholds in lactose intolerance and galactosaemia. EFSA J. 2010;8:1777.

47. Beuchat LR. Surface disinfection of raw produce. Dairy Food Environ. Sanit. 1992;12:6-9.

48. Health Protection Agency. Guidelines for Assessing the Microbiological Safety of Ready-to-Eat Foods; Health Protection Agency: London, UK; 2009.

49. Barth M, Hankinson T, Zhuang H, Breidt F. Microbiological Spoilage of Fruit and Vegetables. In Compendium of the Microbiological Spoilage of Foods and Beverages; Sperber, W.H., Doyle, M.P. Eds.; Springer: New York, NY, USA. 2009;135-183.

50. Tauxe R, Kruse H, Hedberg C, Potter M, Madden J, Wachsmuth K. Microbiological Hazards and Emerging Issues Associated with Produce: A Preliminary Report to the National Advisory Committee on Microbiological Criteria for Foods. J. Food Prot. 1997;60:1400-1408.

51. Abadias M, Usall J, Anguera M, Solsona C, Viñas I. Microbiological quality of fresh, minimallyprocessed fruit and vegetables, and sprouts from retail establishments. Int. J. Food Microbiol. 2008;123:121-129.

DOI: 10.1016/j.ijfoodmicro.2007.12.013

52. Ponce AG, Roura SI, Del Valle CE, Fritz R. Characterization of native microbial population of Swiss Chard (Beta vulgaris, type cicla). LWT Food Sci. Technol. 2002;35:331-337.

DOI: $10.1006 /$ fstl.2001.0879

53. Beuchat LR. Use of Sanitizers in Raw Fruit and Vegetable Processing. In Minimally Processed Fruits and Vegetables; Alzamora, S.M., Tapia, M.S., Lopez-Malo, A. Eds.; An Aspen Publication: Gaithersburg, MD, USA. 2000;63-78.

54. Nykänen A, Lapveteläinen A, Kallio H, Salminen S. Effects of whey, whey-derived lactic acid and sodium lactate on the surface microbial counts of rainbow trout packed in vacuum pouches. LWT Food Sci. Technol. 1998;31:361-365.

DOI: 10.1006/fstl.1998.0372.

55. Yang E, Fan L, Jiang Y, Doucette C, Fillmore S. Antimicrobial activity of bacteriocin-producing lactic acid bacteria isolated from cheeses and yogurts. AMB Express. 2012;2:48. DOI: 10.1186/2191-0855-2-48.

(C) Copyright (2021): Author(s). The licensee is the publisher (B P International).

DISCLAIMER

This chapter is an extended version of the article published by the same author(s) in the following journal. Appl. Sci., 9(2800), 2019. 